\title{
Potassium Permanganate as an Oxidant for a Microfluidic Direct Formate Fuel Cell
}

\author{
Chunmei Liu ${ }^{1, *}$, Haihua Liu², Lei Liu \\ ${ }^{1}$ Institute of Vehicle and Transportation Engineering, Henan University of Science and Technology, \\ Luoyang 471003, Henan Province, China \\ ${ }^{2}$ School of Energy and Architecture, Xi'an Aeronautics University, Xi'an 710000, Shaanxi Province, \\ China \\ ${ }^{3}$ China Nonferrous Metals Processing Technology Co., Ltd., Luoyang 471003, Henan Province, China \\ *E-mail: liuchm800226@163.com
}

doi: $10.20964 / 2019.05 .01$

Received: 18 January 2019 / Accepted: 22 February 2019 / Published: 10 April 2019

\begin{abstract}
A simple Y-type microfluidic fuel cell (MFC) was constructed with graphite plates as the electrodes. Unlike the formic acid/potassium permanganate MFCs previously reported, an alkaline sodium formate solution (a fuel) and an acid potassium permanganate solution $\left(\mathrm{KMnO}_{4}\right.$, an oxidant) were adopted by our MFC. The flowing pattern in the main channel was a typical laminar flow. The effects of three parameters such as the concentrations of $\mathrm{KMnO}_{4}$, the concentrations of $\mathrm{H}_{2} \mathrm{SO}_{4}$ (a supporting catholyte), and the flow rates of the reactants on the power output of the MFC were studied. The experimental results showed that the cell performance first improved but then decreased with increasing each parameter. The optimum MFC exhibited a maximum power density of $4.51 \mathrm{~mW} \mathrm{~cm} \mathrm{~cm}^{-2}$ and a limiting current density of $6.67 \mathrm{~mA} \mathrm{~cm}^{-2}$ with $50 \mathrm{mM} \mathrm{KMnO}_{4}, 0.5 \mathrm{M} \mathrm{H}_{2} \mathrm{SO}_{4}$ and a reactant flow rate of $30 \mathrm{~mL} \mathrm{~h}^{-1}$. Although the power densities and limiting current densities of our MFC are not the highest in the MFCs using $\mathrm{KMnO}_{4}$ as oxidants, its open circuit voltage remains at the top. Our work demonstrates that it is feasible to construct MFCs using alkaline formate and acidic permanganate solutions, which diversifies the types of MFCs containing $\mathrm{KMnO}_{4}$ as the oxidant.
\end{abstract}

Keywords: Microfluidic fuel cells; Potassium permanganate; Supporting catholyte concentration; Reactant flow rate; Open circuit voltage

\section{$\underline{\text { FULL TEXT }}$}

(C) 2019 The Authors. Published by ESG (www.electrochemsci.org). This article is an open access article distributed under the terms and conditions of the Creative Commons Attribution license (http://creativecommons.org/licenses/by/4.0/). 